\title{
Penggunaan Permainan Kartu Gebrak (Karak) untuk Evaluasi Pembelajaran Fisika
}

\author{
Jovi Yuzzer Budiman ${ }^{1}$, Debora Natalia Sudjito ${ }^{1, *}$, Giner Maslebu ${ }^{2}$ \\ ${ }^{1}$ Jurusan Pendidikan Fisika \\ ${ }^{2}$ Jurusan Fisika \\ Fakultas Sains dan Matematika, Universitas Kristen Satya Wacana, Salatiga, Jawa Tengah 50711 \\ *email korespondensi: debora.natalia@staff.uksw.edu
}

\begin{abstract}
ABSTRAK
Rendahnya prestasi belajar yang diraih oleh peserta didik pada pembelajaran fisika bisa jadi dipengaruhi oleh kondisi psikis peserta didik saat mengerjakan evaluasi. Peserta didik cenderung merasa takut, tertekan, atau merasa materi yang dievaluasikan terlalu sulit yang berdampak pada pengerjaan evaluasi yang tidak maksimal. Permainan karak dalam penelitian ini merupakan permainan kartu yang mengadopsi permainan kartu gebrakan yang diintegrasikan dengan pembelajaran kooperatif tipe TGT sebagai metode evaluasi untuk menciptakan suasana evaluasi pembelajaran yang menyenangkan. Penelitian ini menyelidiki bagaimana desain media permainan karak agar dapat digunakan untuk melakukan evaluasi pembelajaran yang menyenangkan serta bagaimana efektivitas media permainan karak sebagai media evaluasi pembelajaran yang menyenangkan. Responden penelitian ini adalah 20 mahasiswa Fisika dan Pendidikan Fisika tingkat pertama. Berdasarkan data yang diperoleh dari lembar observasi, kuesioner, dan rekapitulasi nilai responden, dapat disimpulkan bahwa permainan karak efektif digunakan untuk evaluasi pembelajaran yang menyenangkan, dapat menunjukkan konsep-konsep yang sudah maupun belum dipahami oleh peserta didik, namun kurang rileks bagi peserta didik. Metode evaluasi permainan karak yang telah mendapatkan penilaian memuaskan dalam hal "menyenangkan" tetapi tetap saja menghasilkan nilai kognitif dari hasil evaluasi yang kurang memuaskan. Jadi sebaik apapun metode evaluasi yang dilakukan tetapi tidak didukung dengan keberhasilan proses pembelajaran, maka hasil yang didapatkan akan tetap kurang memuaskan.
\end{abstract}

Kata-kata kunci: evaluasi pembelajaran; menyenangkan; permainan kartu

\section{PENDAHULUAN}

Pendidikan adalah suatu usaha yang dilakukan untuk mengembangkan kemampuan dan kepribadian individu melalui proses atau kegiatan tertentu yang meliputi 3 (tiga) hal yakni pengajaran, bimbingan dan latihan. Di Indonesia, ada delapan standar nasional pendidikan (Soleh dkk, 2009)yang tertulis dalam Undang-undang No. 20 dan 23 tahun 2003 tentang standar penilaian pendidikan yang berkaitan dengan mekanisme, prosedur, dan instrumen penilaian hasil belajar dari peserta didik serta sistem pendidikan nasional yang membahas perihal evaluasi pendidikan dimana evaluasi merupakan suatu kegiatan pengendalian, penjaminan dan penetapan mutu pendidikan sebagai bentuk pertanggungjawaban penyelenggaraan pendidikan dan evaluasi hasil belajar peserta didik yang bertujuan untuk memantau proses, kemajuan, dan perbaikan hasil belajar peserta didik (Arifin, 2009).

Pengertian evaluasi adalah suatu proses yang sistematis dan berguna untuk mengumpulkan, mendeskripsikan, menginterpretasikan dan menyajikan informasi tentang suatu program untuk dapat digunakan sebagai dasar membuat keputusan, menyusun kebijakan maupun menyusun program selanjutnya yang berarti evaluasi pembelajaran terhadap peserta didik dapat digunakan sebagai dasar membuat keputusan dalam menyusun kebijakan maupun program pembelajaran selanjutnya (Putro, 2009). Pentingnya peran dari evaluasi pembelajaran terhadap peserta didik menuntut setiap pendidik untuk dapat melakukan evaluasi pembelajaran dengan menarik dikarenakan proses evaluasi pembelajaran bukan merupakan suatu hal yang dinantikan oleh peserta didik karena dianggap tidak menyenangkan bagi mereka, hal ini disebabkan oleh pengalaman belajar serta evaluasi yang dialami peserta didik sehingga tujuan pembelajaran menjadi sulit untuk dicapai dan juga dapat dilihat dari rendahnya nilai rata-rata mata pelajaran (Sugiharti, 2011). Rendahnya prestasi belajar yang diraih oleh peserta didik pada pembelajaran fisika dipengaruhi oleh kondisi psikis peserta didik saat mengerjakan evaluasi yang merupakan salah satu faktor internal yang mempengaruhi hasil belajar seorang peserta didik (Ahmad, 2014). Peserta didik cenderung merasa takut, tertekan, atau merasa materi yang dievaluasikan terlalu sulit. Hal ini berdampak 
pada hasil evaluasi yang tidak menyatakan kondisi siswa yang sesungguhnya karena pengerjaan evaluasi yang tidak maksimal (Syah, 2012).

Sebagian besar pendidik belum kreatif menciptakan suasana evaluasi yang menyenangkan sehingga diperlukan suatu metode evaluasi yang menarik sebagai strategi dalam memaksimalkan hasil evaluasi (Kristiyono, 2008). Hal inilah yang menjadi dasar dibuatnya permainan kartu gebrak (karak) ini. Permainan karak dalam penelitian ini merupakan permainan kartu yang mengadopsi permainan kartu (Sugiyarni dkk, 2014) 20 gebrakan yang diintegrasikan dengan pembelajaran kooperatif tipe Teams Game Tournament (TGT) sebagai metode evaluasi untuk menciptakan suasana evaluasi pembelajaran yang menyenangkan (Arsita dkk, 2016, Kartika dkk, 2016, Simon dkk, 2016). Penelitian ini menyelidiki bagaimana desain media permainan karak agar dapat digunakan untuk melakukan evaluasi pembelajaran yang menyenangkan serta bagaimana efektivitas media permainan karak sebagai media evaluasi pembelajaran yang menyenangkan. Karakteristik evaluasi yang menyenangkan diantaranya adalah peserta didik merasa tidak bosan, bersemangat dalam mengerjakan soal, santai dalam mengikuti rangkaian evaluasi pembelajaran, dan tidak terlihat mengantuk.

Penelitian ini bertujuan untuk membuat desain media pembelajaran dengan permainan kartu yang efektif untuk evaluasi pembelajaran yang menyenangkan, peserta didik dapat mengerjakan proses evaluasi dengan maksimal, serta mendapatkan hasil sesuai dengan keadaan peserta didik yang sesungguhnya.

\section{EKSPERIMEN}

Penelitian ini merupakan penelitian deskriptif. Materi pembelajaran fisika yang diangkat adalah tentang cermin cekung pada matakuliah Optika Geometri. Adapun responden penelitian ini adalah 20 mahasiswa Fisika dan Pendidikan Fisika tingkat pertama. Instrumen penelitian untuk pengambilan data yang dilakukan meliputi 2 (dua): (1) Lembar Observasi KBM untuk merekam jalannya evaluasi pembelajaran yang menggunakan media permainan karak. (2) Lembar Kuesioner untuk mengetahui tanggapan peserta didik terhadap media permainan karak.

\section{PROSEDUR KERJA}

Kegiatan pengambilan data meliputi 2 tahap : (1) pembuatan kartu soal serta aturan permainan karak, lembar observasi KBM, dan lembar kuesioner dan (2) kegiatan turnamen pada tahap konsolidasi pembelajaran dengan mengimplementasikan CL TGT menggunakan permainan karak sebagai media evaluasi pembelajaran; aturan permainan karak selengkapnya dijelaskan pada bagan di Gambar 1. Pengambilan data ini dilakukan setelah pembelajaran cermin cekung. Pembelajaran tentang cermin cekung dilakukan oleh dosen pengampu matakuliah Optika Geometri.

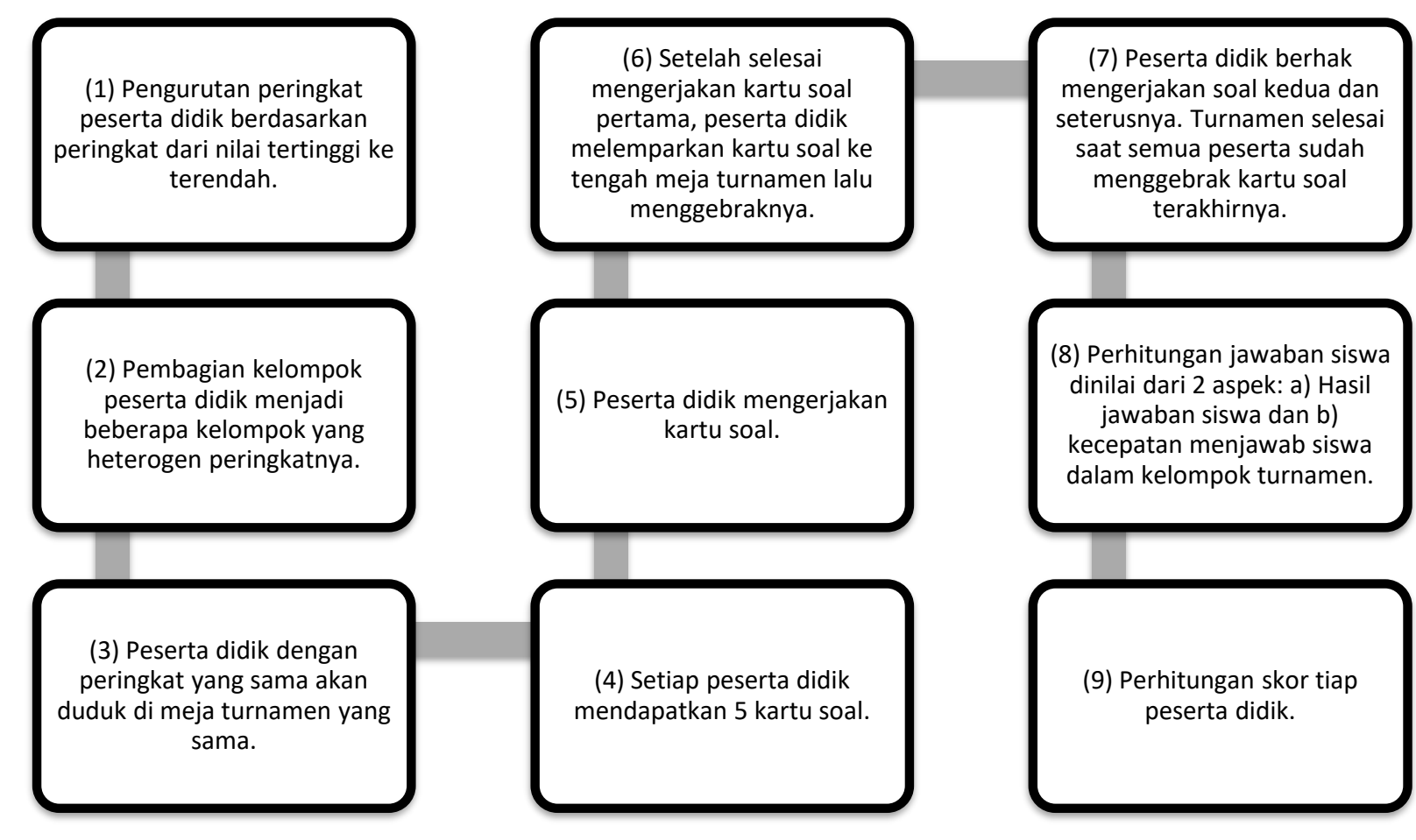

Gambar 1. Aturan permainan Karak 
Setelah pembelajaran, pada tahap konsolidasi, evaluasi pembelajaran berupa permainan karak dimainkan dengan CL tipe TGT. Aturan permainan dibuat sesuai dengan kebutuhan evaluasi. Pertama, setiap peserta didik diberikan kode untuk dibagi ke beberapa kelompok yang heterogen peringkatnya seperti pada Gambar 2 berdasarkan performa mereka di selama perkuliahan. Peserta didik dengan peringkat 1-4 diberi kode $A 1, B 1, C 1, D 1$, peringkat 5-8 diberi kode $A 2, B 2, C 2, D 2$, peringkat 9-12 diberi kode A3, B3, C3, D3, peringkat 13-16 diberi kode A4, B4, C4, D4, peringkat 17-20 diberi kode A5, B5, C5, D5 dan akan duduk di meja turnamen dengan peringkat yang sama. Hasil pengelompokan tersebut dapat dilihat pada Gambar 3.

Daftar Kelompok
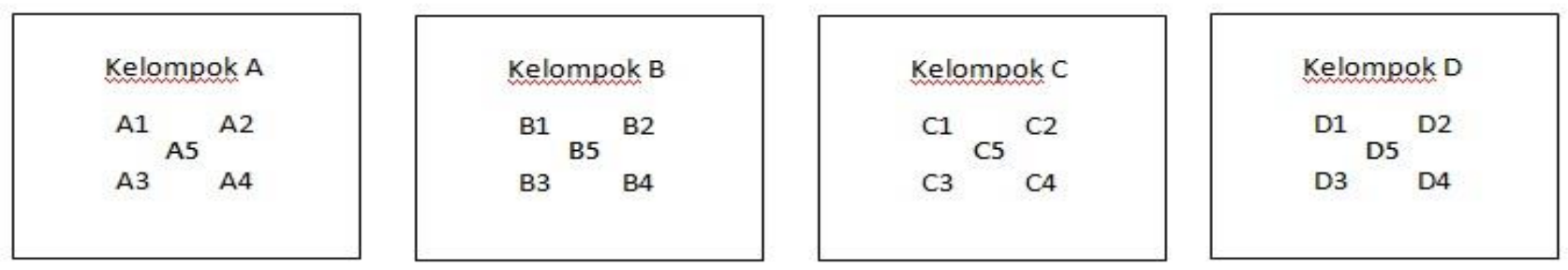

Gambar 2. Daftar Kelompok

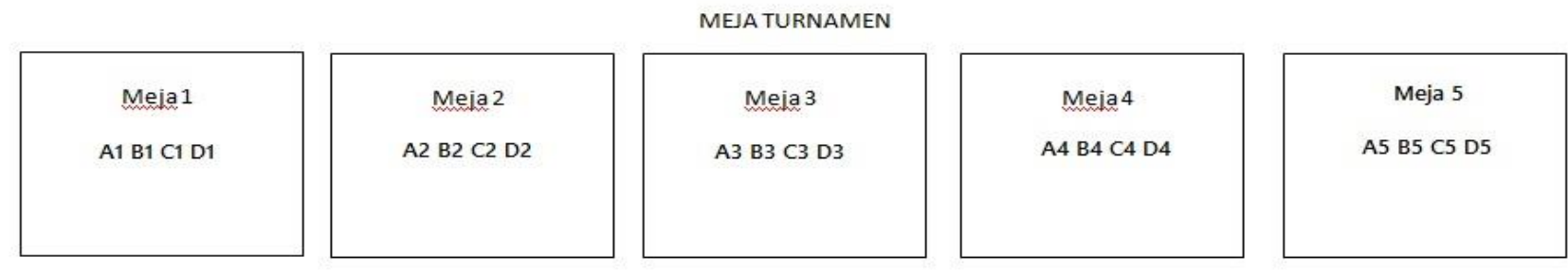

Gambar 3. Meja Turnamen

Setelah pembagian kelompok dan seluruh peserta didik telah menempati meja turnamen masingmasing, setiap peserta didik diberikan 5 kartu soal yang sama. Peserta didik dipersilakan mengerjakan kartu soal pertama dan setelah selesai mengerjakan, peserta didik melemparkan kartu soalnya ke tengah meja turnamen dan menggebraknya kemudian peserta didik berhak mengerjakan soal kedua, demikian seterusnya sampai kartu soal terakhir. Setelah semua peserta didik mengerjakan semua kartu soal, maka dilakukan perhitungan hasil jawaban yang telah dikerjakan. Perhitungan jawaban peserta didik dinilai dari dua kriteria : (1) hasil jawaban peserta didik dan (2) kecepatan menjawab peserta didik dalam kelompok turnamen masing-masing. Kriteria penilaian dapat dililhat pada Tabel 1.

Tabel 1. Perhitungan hasil jawaban peserta didik per meja turnamen

\begin{tabular}{|c|c|c|c|}
\hline \multirow{2}{*}{$\begin{array}{c}\text { Urutan } \\
\text { menjawab peserta didik }\end{array}$} & \multicolumn{2}{|c|}{ Hasil menjawab peserta didik } & \multirow{2}{*}{$\begin{array}{c}\text { ilai berdasarkan kecepatan } \\
\text { menjawab peserta didik }\end{array}$} \\
\cline { 2 - 3 } & Jawaban Benar & Jawaban Salah & 3 \\
\hline 1 & 7 & 3,5 & 2,7 \\
\hline 3 & 6,3 & 3,5 & 2,4 \\
\hline 4 & 5,6 & 3,5 & 2,1 \\
\hline 5 & 4,9 & 3,5 & 1,8 \\
\hline
\end{tabular}

\footnotetext{
** Keterangan
}

Jawaban Benar : Nilai yang diperoleh peserta didik saat menjawab soal dengan benar.

Jawaban Salah : Nilai yang diperoleh peserta didik saat menjawab soal dengan salah.

Kecepatan menjawab peserta didik : Nilai yang diperoleh peserta didik dari urutan kecepatan menjawab soal.

Nilai akhir dari setiap kartu soal adalah nilai hasil menjawab peserta didik dijumlahkan dengan nilai kecepatan menjawab peserta didik. Bobot nilai dari setiap nomor yang benar terdiri dari dua perolehan skor yakni (1) 70\% dari jumlah keseluruhan nilai untuk hasil jawaban benar, dimana jika jawaban salah, peserta hanya mendapatkan nilai sebesar 3,5 dan (2) 30\% nilai untuk kecepatan menjawab siswa dari tiap nomornya. Nilai akhir tiap peserta didik tiap kelompok dipengaruhi oleh tiap anggota kelompoknya. Sebagai contoh, skor hasil turnamen peserta didik A1 mempunyai perhitungan $A 1=\frac{(n 1+n 2+n 3+n 4+n 5)}{5}$ dimana $\mathrm{n}$ adalah skor dari tiap kartu soal yang didapatkan dari penjumlahan nilai hasil menjawab peserta didik dengan nilai kecepatan menjawab peserta didik. Nilai akhir tiap peserta didik adalah rata-rata akumulasi 
skor kelompoknya. Sebagai contoh, nilai akhir kelompok $A(A 1, A 2, A 3, A 4, A 5)$ mempunyai perhitungan $\frac{(A 1+A 2+A 3+A 4+A 5)}{5}$ dan masing-masing peserta didik akan mendapatkan nilai yang sama pada setiap kelompoknya. (Nilai akhir A1 = Nilai akhir A2 = Nilai akhir A3 = Nilai akhir A4 = Nilai akhir A5).

\section{TEKNIK ANALISA DATA}

Semua data yang diperoleh dari kartu soal, lembar observasi, dan kuesioner dianalisis secara deskriptif kualitatif. Media evaluasi permainan kartu karak dikatakan efektif untuk evaluasi pembelajaran yang menyenangkan jika minimal $70 \%$ peserta didik memberikan respon positif terhadap pernyataan di lembar observasi KBM dan kuesioner. Respon positif di lembar observasi berupa peserta didik memperoleh skor minimal 3 pada setiap aspek observasi. Respon positif di kuesioner berupa peserta didik memberikan pernyataan "ya" di ketiga aspek kuesioner.

\section{HASIL DAN DISKUSI}

Hasil pengamatan observer direkam dalam Tabel 2, hasil tanggapan peserta didik direkam dalam Tabel 3, dan nilai dari kartu soal dan permainan karak direkam dalam Tabel 4. Dari lembar observasi pada Tabel 2, didapatkan bahwa seluruh peserta didik (100\%) mempunyai minat untuk mengikuti proses evaluasi (permainan karak), evaluasi yang dilakukan menyenangkan bagi peserta didik, serta peserta didik dapat mengerjakan semua soal dalam waktu yang relatif singkat. Namun hanya $50 \%$ peserta didik yang memahami materi cermin cekung.

Hasil pengamatan yang terekam di lembar observasi pada Tabel 2 tadi senada dengan tanggapan responden di lembar kuesioner pada Tabel 3. Pada kuesioner, didapatkan bahwa $100 \%$ peserta didik senang dan dapat mengenali konsep-konsep cermin cekung yang sudah maupun belum dipahami oleh peserta didik, sedangkan sebanyak $45 \%$ peserta didik rileks dalam menghadapi evaluasi pembelajaran dengan karak, artinya lebih banyak peserta didik yang tidak rileks saat menjalani proses rangkaian evaluasi yang dimana didapatkan. Hal ini dikuatkan dari tanggapan yang ditulis oleh $40 \%$ peserta didik yang menyatakan bahwa mereka tergesa-gesa saat mengerjakan evaluasi pembelajaran. Hal ini juga yang menyebabkan persentase peserta didik yang menjawab benar hanya $50 \%$. Jadi berdasarkan data pada lembar observasi dan kuesioner, permainan karak dapat dikatakan efektif untuk digunakan sebagai metode evaluasi yang menyenangkan serta dapat membedakan submateri yang sudah dan belum dipahami oleh peserta didik, tetapi belum dapat membuat peserta didik merasa rileks dalam mengerjakan evaluasi pembelajaran.

Dari kedua data di lembar observasi dan lembar kuesioner tadi, menarik untuk dikaji mengapa pada evaluasi yang menyenangkan, justru didapati pemahaman siswa yang kurang. Hal ini dapat dikaji dari rekapitulasi nilai kartu gebrak di Tabel 4, didapatkan bahwa rata-rata jumlah peserta didik yang menjawab kelima soal dengan benar adalah $54 \%$. Lebih rinci lagi, pada soal nomor 2 dan 4 ada sebanyak $\geq 70 \%$ peserta didik yang menjawab benar, sedangkan pada nomor 1,3 , dan 5 hanya $<70 \%$ peserta didik menjawab benar. Secara spesifik, soal nomor 2 dan 4 merupakan soal dengan konsep dasar dan yang paling mudah karena cenderung berupa soal hafalan, sedangkan soal nomor 1, 3, dan 5 merupakan soal terapan dan analisa sehingga ada variasi dari latihan soal yang diberikan. Hal ini menunjukkan bahwa jenis soal dalam karak sudah cukup baik untuk membedakan konsep/submateri yang mana yang sudah dipahami oleh peserta didik dan mana yang belum. Ternyata peserta didik baru mampu mengerjakan soal pada level dasar (Low Order Thinking), belum mampu mengerjakan soal pada level tinggi (High Order Thinking). Hal ini juga nampak pada hasil tes akhir mata kuliah Optika Geometri yang mencakup materi cermin cekung, hanya $10 \%$ peserta didik yang memperoleh nilai di atas 70 . Ada 2 faktor yang mempengaruhi hasil belajar peserta didik yakni faktor eksternal dan internal (Saputra, 2017). Beberapa contoh faktor eksternal adalah (1) keluarga (cara orangtua mendidik, relasi antar anggota keluarga, suasana rumah, keadaan ekonomi keluarga, pengertian orangtua dan latar belakang kebudayaan), (2) faktor sekolah (metode mengajar, kurikulum, relasi guru dengan peserta didik, relasi antar peserta didik, disiplin sekolah, alat pelajaran, waktu sekolah, standar pelajaran yang akan dicapai, keadaan gedung, metode belajar, dan tugas rumah), dan (3) faktor masyarakat (seperti kegiatan peserta didik dalam masyarakat, media masa, teman bergaul, dan bentuk kehidupan masyarakat), serta beberapa faktor internal yang berasal dari dalam diri peserta didik adalah (1) faktor jasmaniah (kesehatan dan cacat tubuh), (2) faktor psikologis (intelegensi, perhatian, minat, bakat, motif, kematangan, dan kesiapan) dan (3) faktor kelelahan (jasmani dan rohani). 
Ketika wawancara lanjutan dilakukan, didapatkan fakta dari dosen pengajar dan responden penelitian bahwa jeda antara pembelajaran dan permainan karak cukup lama yakni sekitar 3 minggu. Keadaan ini bisa jadi membuat mahasiswa lupa konsep yang sudah dipelajari, apalagi jika pada saat pembelajaran memang mereka belum benar-benar paham. Ditambah lagi dengan rasa kurang rileks dan tergesa-gesa yang mereka alami selama permainan karak, secara psikis akan mengurangi konsentrasi mereka saat mengerjakan soal sehingga hasil tes mereka kurang memuaskan. Dengan demikian, tampak bahwa yang menyebabkan mereka kurang paham bukan di metode evaluasinya tetapi di proses pembelajarannya, baik cara belajar peserta didik maupun metode pembelajaran pengajar. Kualitas hasil belajar yang baik ditentukan dari kualitas belajar peserta didik seperti dalam hal mempersiapkan diri untuk belajar, mengikuti pembelajaran, dan juga pola belajar khususnya dalam hal aktivitas belajar mandiri.

Tabel 2. Lembar Observasi

\begin{tabular}{|c|c|c|c|c|c|}
\hline \multirow[b]{2}{*}{ Peserta Didik } & \multicolumn{4}{|c|}{ Aspek Observasi } & \multirow[b]{2}{*}{ Total } \\
\hline & $\begin{array}{c}\text { Minat } \\
\text { Peserta Didik }\end{array}$ & $\begin{array}{l}\text { Evaluasi yang } \\
\text { Menyenangkan }\end{array}$ & $\begin{array}{l}\text { Pemahaman } \\
\text { Peserta Didik }\end{array}$ & $\begin{array}{l}\text { Efisiensi } \\
\text { Waktu }\end{array}$ & \\
\hline $\mathrm{A} 1$ & 4 & 4 & 2 & 4 & 14 \\
\hline $\mathrm{A} 2$ & 4 & 4 & 2 & 4 & 14 \\
\hline A3 & 4 & 4 & 3 & 4 & 15 \\
\hline A4 & 4 & 4 & 1 & 3 & 12 \\
\hline A5 & 4 & 4 & 2 & 4 & 14 \\
\hline B1 & 4 & 4 & 4 & 4 & 16 \\
\hline B2 & 4 & 4 & 2 & 4 & 14 \\
\hline B3 & 4 & 4 & 4 & 4 & 16 \\
\hline B4 & 4 & 4 & 4 & 4 & 16 \\
\hline B5 & 4 & 4 & 3 & 4 & 15 \\
\hline $\mathrm{C} 1$ & 4 & 4 & 4 & 4 & 16 \\
\hline $\mathrm{C} 2$ & 4 & 4 & 3 & 4 & 15 \\
\hline $\mathrm{C} 3$ & 4 & 4 & 1 & 4 & 13 \\
\hline $\mathrm{C} 4$ & 4 & 4 & 4 & 4 & 16 \\
\hline $\mathrm{C} 5$ & 4 & 4 & 2 & 3 & 13 \\
\hline D1 & 4 & 4 & 1 & 4 & 13 \\
\hline D2 & 4 & 4 & 1 & 4 & 13 \\
\hline D3 & 4 & 4 & 3 & 4 & 15 \\
\hline D4 & 4 & 4 & 2 & 4 & 14 \\
\hline D5 & 4 & 4 & 4 & 4 & 16 \\
\hline \multicolumn{5}{|c|}{ Rata-rata } & 14,5 \\
\hline $\begin{array}{l}\text { Persentase jumlah peserta didik yang } \\
\text { mendapat poin minimal } 3(\%)\end{array}$ & 100 & 100 & 50 & 100 & \\
\hline
\end{tabular}

Tabel 3. Hasil Kuesioner

\begin{tabular}{|c|l|c|}
\hline Nomor & \multicolumn{1}{|c|}{ Pertanyaan } & $\begin{array}{c}\text { Persentase Jumlah Peserta Didik } \\
\text { yang Menjawab Ya (\%) }\end{array}$ \\
\hline 1 & $\begin{array}{l}\text { Apakah permainan karak ini membuat anda mengalami evaluasi } \\
\text { pembelajaran yang menyenangkan? }\end{array}$ & 100 \\
\hline 2 & $\begin{array}{l}\text { Apakah soal-soal yang diberikan dalam permainan karak ini } \\
\text { membuat anda mengenali konsep-konsep cermin cekung yang } \\
\text { sudah dan belum anda pahami ? }\end{array}$ & 100 \\
\hline 3 & $\begin{array}{l}\text { Apakah evaluasi pembelajaran yang dikemas dalam permainan } \\
\text { karak ini membuat anda menjadi lebih rileks dalam } \\
\text { menghadapinya? }\end{array}$ \\
\hline
\end{tabular}


Jurnal Sains dan Edukasi Sains, Vol.2, No.1, Februari 2019: 8-15

Tabel 4. Rekapitulasi Nilai Siswa dari Permainan Karak

\begin{tabular}{|c|c|c|c|c|c|c|c|c|c|c|c|c|c|c|}
\hline \multirow{2}{*}{ Kelompok } & \multicolumn{5}{|c|}{ Nilai Jawaban Tiap Nomor (X) } & \multirow{2}{*}{$\begin{array}{l}\text { Total } \\
(\mathrm{X})\end{array}$} & \multicolumn{5}{|c|}{ Nilai Kecepatan Tiap Nomor (Y) } & \multirow{2}{*}{$\begin{array}{l}\text { Total } \\
(\mathrm{Y})\end{array}$} & \multirow{2}{*}{$\begin{array}{l}\text { Nilai } \\
\text { Total } \\
(\mathrm{X}+\mathrm{Y})\end{array}$} & \multirow{2}{*}{$\begin{array}{l}\text { Nilai Akhir } \\
(\mathrm{X}+\mathrm{Y}) / 5\end{array}$} \\
\hline & 1 & 2 & 3 & 4 & 5 & & 1 & 2 & 3 & 4 & 5 & & & \\
\hline $\mathrm{A} 1$ & 3,50 & 6,30 & 4,90 & 3,50 & 3,50 & 21,70 & 2,10 & 2,70 & 2,10 & 2,40 & 2,40 & 11,70 & 33,40 & 6,68 \\
\hline $\mathrm{A} 2$ & 3,50 & 5,60 & 3,50 & 5,60 & 3,50 & 21,70 & 2,40 & 2,40 & 2,40 & 2,40 & 2,10 & 11,70 & 33,40 & 6,68 \\
\hline A3 & 3,50 & 6,30 & 3,50 & 6,30 & 6,30 & 25,90 & 2,10 & 2,70 & 2,40 & 2,70 & 2,70 & 12,60 & 38,50 & 7,70 \\
\hline A4 & 3,50 & 7,00 & 3,50 & 3,50 & 3,50 & 21,00 & 2,70 & 3,00 & 2,70 & 2,10 & 2,10 & 12,60 & 33,60 & 6,72 \\
\hline A5 & 3,50 & 7,00 & 3,50 & 5,60 & 3,50 & 23,10 & 2,70 & 3,00 & 2,10 & 2,40 & 2,70 & 12,90 & 36,00 & 7,20 \\
\hline \multicolumn{14}{|c|}{ Nilai Total Kelompok A } & 7,00 \\
\hline B1 & 5,60 & 5,60 & 5,60 & 6,30 & 3,50 & 26,60 & 2,40 & 2,40 & 2,40 & 2,70 & 2,70 & 12,60 & 39,20 & 7,84 \\
\hline B2 & 3,50 & 7,00 & 3,50 & 6,30 & 3,50 & 23,80 & 2,10 & 3,00 & 2,70 & 2,70 & 3,00 & 13,50 & 37,30 & 7,46 \\
\hline B3 & 3,50 & 7,00 & 7,00 & 7,00 & 7,00 & 31,50 & 3,00 & 3,00 & 3,00 & 3,00 & 3,00 & 15,00 & 46,50 & 9,30 \\
\hline B4 & 7,00 & 5,60 & 5,60 & 6,30 & 6,30 & 30,80 & 3,00 & 2,40 & 2,40 & 2,70 & 2,70 & 13,20 & 44,00 & 8,80 \\
\hline B5 & 3,50 & 6,30 & 3,50 & 6,30 & 5,60 & 25,20 & 2,40 & 2,70 & 3,00 & 2,70 & 2,40 & 13,20 & 38,40 & 7,68 \\
\hline \multicolumn{14}{|c|}{ Nilai Total Kelompok B } & 8,22 \\
\hline $\mathrm{C} 1$ & 6,30 & 4,90 & 7,00 & 7,00 & 7,00 & 32,20 & 2,70 & 2,10 & 3,00 & 3,00 & 3,00 & 13,80 & 46,00 & 9,20 \\
\hline $\mathrm{C} 2$ & 7,00 & 4,90 & 3,50 & 3,50 & 5,60 & 24,50 & 3,00 & 2,10 & 3,00 & 3,00 & 2,40 & 13,50 & 38,00 & 7,60 \\
\hline $\mathrm{C} 3$ & 3,50 & 4,90 & 3,50 & 3,50 & 3,50 & 18,90 & 2,40 & 2,10 & 2,10 & 2,40 & 2,40 & 11,40 & 30,30 & 6,06 \\
\hline $\mathrm{C} 4$ & 4,90 & 6,30 & 4,90 & 5,60 & 3,50 & 25,20 & 2,10 & 2,70 & 2,10 & 2,40 & 2,40 & 11,70 & 36,90 & 7,38 \\
\hline $\mathrm{C} 5$ & 3,50 & 4,90 & 3,50 & 4,90 & 3,50 & 20,30 & 2,10 & 2,10 & 2,40 & 2,10 & 2,10 & 10,80 & 31,10 & 6,22 \\
\hline \multicolumn{14}{|c|}{ Nilai Total Kelompok C } & 7,29 \\
\hline D1 & 3,50 & 3,50 & 6,30 & 3,50 & 3,50 & 20,30 & 3,00 & 3,00 & 2,70 & 2,10 & 2,10 & 12,90 & 33,20 & 6,64 \\
\hline $\mathrm{D} 2$ & 3,50 & 3,50 & 3,50 & 4,90 & 3,50 & 18,90 & 2,70 & 2,70 & 2,10 & 2,10 & 2,70 & 12,30 & 31,20 & 6,24 \\
\hline D3 & 3,50 & 5,60 & 6,30 & 4,90 & 3,50 & 23,80 & 2,70 & 2,40 & 2,70 & 2,10 & 2,10 & 12,00 & 35,80 & 7,16 \\
\hline D4 & 5,60 & 4,90 & 3,50 & 3,50 & 3,50 & 21,00 & 2,40 & 2,10 & 3,00 & 3,00 & 3,00 & 13,50 & 34,50 & 6,90 \\
\hline D5 & 3,50 & 5,60 & 6,30 & 7,00 & 7,00 & 29,40 & 3,00 & 2,40 & 2,70 & 3,00 & 3,00 & 14,10 & 43,50 & 8,70 \\
\hline \multicolumn{14}{|c|}{ Nilai Total Kelompok D } & 7,13 \\
\hline $\begin{array}{c}\text { Persentase } \\
\text { siswa yang } \\
\text { menjawab } \\
\text { benar tiap } \\
\text { soal } \\
(\%) \\
\end{array}$ & $30 \%$ & $90 \%$ & $45 \%$ & $70 \%$ & $35 \%$ & & & & & & & & & $54 \%$ \\
\hline \multicolumn{14}{|c|}{ Rata-rata Nilai Total } & 7,41 \\
\hline
\end{tabular}

Tabel 5. Nilai Tes Akhir Matakuliah Optika Geometri

\begin{tabular}{|c|c|c|c|}
\hline Nomor & Nilai & Nomor & Nilai \\
\hline A1 & 58,5 & C1 & 67,0 \\
\hline A2 & 29,0 & C2 & 47,5 \\
\hline A3 & 57,0 & C3 & 29,0 \\
\hline A4 & 22,0 & C4 & 45,0 \\
\hline A5 & 62,5 & C5 & 25,0 \\
\hline B1 & 48,0 & D1 & 15,5 \\
\hline B2 & 38,0 & D2 & 40,0 \\
\hline B3 & 37,0 & D3 & 38,5 \\
\hline B4 & 70,5 & D4 & 55,5 \\
\hline B5 & 27,0 & D5 & 75,0 \\
\hline
\end{tabular}

Jadi walaupun evaluasi yang disajikan sudah baik, menyenangkan, dan efektif, tetapi jika proses belajar dan pembelajaran peserta didik kurang baik, maka hasil pembelajaran khususnya pada aspek kognitif tetap kurang memuaskan. Hal ini dapat dilihat dari data yang diperoleh pada Tabel 3 opsi pertanyaan pertama yang menunjukkan bahwa evaluasi pembelajaran yang dilakukan sudah 
menyenangkan tetapi pada Tabel 4 dan 5, masih terdapat peserta didik yang mendapatkan hasil pembelajaran yang kurang memuaskan. Evaluasi belajar yang baik harus didukung oleh proses pembelajaran yang baik juga. Namun demikian, permainan karak ini efektif digunakan sebagai evaluasi yang menyenangkan karena dapat menarik minat untuk mengikuti proses evaluasi, peserta didik dapat mengerjakan semua soal dalam waktu yang relatif singkat, serta cukup baik untuk membedakan konsep/submateri yang sudah dan belum dipahami oleh peserta didik.

\section{KESIMPULAN}

Berdasarkan data yang diperoleh dari lembar observasi, kuesioner, dan rekapitulasi nilai responden, dapat disimpulkan bahwa kartu dan permainan karak efektif digunakan untuk evaluasi pembelajaran yang menyenangkan, dapat menunjukkan konsep-konsep yang sudah maupun belum dipahami oleh peserta didik, namun kurang rileks bagi peserta didik. Proses evaluasi pembelajaran melalui media permainan karak sudah berhasil membuat peserta didik menjalani proses evaluasi dengan menyenangkan. Proses pembelajaran yang dilakukan terkhusus dalam hal cara belajar peserta didik perlu diperhatikan agar peserta didik dapat mendapatkan hasil yang memuaskan pada saat proses evaluasi belajar. Metode evaluasi permainan karak yang telah mendapatkan penilaian memuaskan dalam hal "menyenangkan" tetapi tetap saja menghasilkan nilai kognitif dari hasil evaluasi yang kurang memuaskan. Apalagi jika metode evaluasi yang dilakukan merupakan metode konvensional yang seringkali dilakukan sebagaimana evaluasi pembelajaran pada umumnya. Jadi sebaik apapun metode evaluasi yang dilakukan tetapi tidak didukung dengan keberhasilan proses pembelajaran, maka hasil yang didapatkan akan tetap kurang memuaskan. Untuk penelitian selanjutnya, permainan karak dapat dikembangkan untuk evaluasi pembelajaran materi fisika yang lain dengan memikirkan cara untuk membuat peserta didik lebih rileks agar peserta didik dapat mengerjakan rangkaian kegiatan evaluasi dengan lebih baik.

\section{DAFTAR PUSTAKA}

Ahmad, A, R., 2014. 'Evaluasi Pembelajaran Aktif Kreatif Efektif dan Menyenangkan dengan Model Context Input Process Product'. Jurnal IImiah Widya. Volume 2 Nomor 2 Mei-Juli 2017. ISSN: 2337-6686.

Arifin, Z. 2009. Evaluasi Pembelajaran. Bandung: PT Remaja Rosdakarya Offset. ISBN: 979-692-956-2.

Arsita, D., Natalia, D., Rai, M. 2016. "Desain Media Pembelajaran Menggunakan Permainan Fun Frame in Physics pada Pokok Bahasan Cermin Cekung Melalui Turnamen". Prosiding Seminar Nasional Quantum. ISSN: 2477-1511

Kartika, Y., Natalia, D., dan Shanti, M. 2016. 'Desain Media Pembelajaran menggunakan Permainan Fun Frame in Physics pada Pokok Bahasan Cermin Datar Melalui turnamen'. Prosiding Seminar Nasional Quantum 2016., ISSN 2477-1511, hh. 27-38.

Kristiyono, H. "Mahir Perkalian Dan Pembagian Bilangan Dasar Melalui Metode Permainan Kartu". Jurnal Pendidikan Penabur. No 10 Tahun ke 7 Juni 2008.

Putro, E. 2009. Evaluasi Program Pembelajaran. Yogyakarta: Pustaka Pelajar. ISBN: 978-602-8479-71-4.

Saputra, S. 2017. 'Hubungan Regulasi Emosi dengan Hasil Belajar Siswa'. KONSELOR. Volume 6 Number 3, pp. 96-100. ISSN: Print 1412-9760.

Simon, D., Natalia, D., Rai, M. 2016. “Desain Media Pembelajaran Menggunakan Permainan Fun Frame in Physics pada Pokok Bahasan Lensa Cekung Melalui Model Turnamen". Prosiding Seminar Nasional Quantum. ISSN: 2477-1511

Soleh, A., Pramono., Suratno. "Faktor-faktor Yang Mempengaruhi Keberhasilan Siswa Kelas 2 TMO SMK Texmaco Semarang Pada Mata Diklat Service Engine Dan Komponen-komponennya". Jurnal PTM. Volume 9, No. 2, Desember 2009. 
Sugiharti, P. 2011. 'Penggunaan Metode SCRAMBLE pada Pembelajaran Fisika untuk Meningkatkan Motivasi Belajar Siswa'. Jurnal Pendidikan Penabur. No. 16 Tahun ke 10, hh. 46-54.

Sugiyarni, L., Sudarmi, M., dan Natalia, D. 2014. 'Penerapan Pembelajaran Kooperatif tipe TGT dengan Media PHYSICS HEARTS CARD pada Materi Momentum dan Impuls'. Radiasi. Vol. 4 No. 1, hh. 9-16.

Syah, M. 2012. Psikologi Belajar. Bandung: RajaGrafindo Persada (Rajawali Perss). ISBN: 979-421-933-9 